\title{
Highly thermostable GH39 $\beta$-xylosidase from a Geobacillus sp. strain WSUCF1
}

\author{
Aditya Bhalla ${ }^{1,3}$, Kenneth M Bischoff ${ }^{2}$ and Rajesh K Sani ${ }^{{ }^{*}}$
}

\begin{abstract}
Background: Complete enzymatic hydrolysis of xylan to xylose requires the action of endoxylanase and $\beta$-xylosidase. $\beta$-xylosidases play an important part in hydrolyzing xylo-oligosaccharides to xylose. Thermostable $\beta$-xylosidases have been a focus of attention as industrially important enzymes due to their long shelf life and role in the relief of end-product inhibition of xylanases caused by xylo-oligosaccharides. Therefore, a highly thermostable $\beta$-xylosidase with high specific activity has significant potential in lignocellulose bioconversion.

Results: A gene encoding a highly thermostable GH39 $\beta$-xylosidase was cloned from Geobacillus sp. strain WSUCF1 and expressed in Escherichia coli. Recombinant $\beta$-xylosidase was active over a wide range of temperatures and $\mathrm{pH}$ with optimum temperature of $70^{\circ} \mathrm{C}$ and $\mathrm{pH}$ 6.5. It exhibited very high thermostability, retaining $50 \%$ activity at $70^{\circ} \mathrm{C}$ after 9 days. WSUCF1 $\beta$-xylosidase is more thermostable than $\beta$-xylosidases reported from other thermophiles (growth temperature $\leq 70^{\circ} \mathrm{C}$. Specific activity was $133 \mathrm{U} / \mathrm{mg}$ when incubated with $p$-nitrophenyl xylopyranoside, with $\mathrm{K}_{\mathrm{m}}$ and $V_{\max }$ values of $2.38 \mathrm{mM}$ and $147 \mathrm{U} / \mathrm{mg}$, respectively. SDS-PAGE analysis indicated that the recombinant enzyme had a mass of $58 \mathrm{kDa}$, but omitting heating prior to electrophoresis increased the apparent mass to $230 \mathrm{kDa}$, suggesting the enzyme exists as a tetramer. Enzyme exhibited high tolerance to xylose, retained approximately $70 \%$ of relative activity at $210 \mathrm{mM}$ xylose concentration. Thin layer chromatography showed that the enzyme had potential to convert xylo-oligomers (xylobiose, triose, tetraose, and pentaose) into fermentable xylose. WSUCF1 $\beta$-xylosidase along with WSUCF1 endo-xylanase synergistically converted the xylan into fermentable xylose with more than $90 \%$ conversion.

Conclusions: Properties of the WSUCF1 $\beta$-xylosidase i.e. high tolerance to elevated temperatures, high specific activity, conversion of xylo-oligomers to xylose, and resistance to inhibition from xylose, make this enzyme potentially suitable for various biotechnological applications.
\end{abstract}

Keywords: Lignocellulose, Biofuels, $\beta$-xylosidase, Thermostable

\section{Background}

Xylan represents the second most abundant polysaccharide in the biosphere after cellulose, and therefore is a potential source of sugars for the production of biofuels. Complete degradation of xylan to monomeric sugars requires synergistic action of several xylanolytic enzymes. Endo-1,4- $\beta$ xylanases (EC 3.2.1.8) hydrolyze the xylan backbone and $\beta$-D-xylosidases (EC 3.2.1.37) sunder the resulting xylooligomers to free xylose [1,2]. Availability of free xylose is immensely important to the overall efficiency of conversion of biomass to biofuels in the fermentation industry.

\footnotetext{
* Correspondence: Rajesh.Sani@sdsmt.edu

'Department of Chemical and Biological Engineering, South Dakota School of Mines and Technology, Rapid City, SD 57701, USA

Full list of author information is available at the end of the article
}

Xylanases have also been suggested to complement the activity of cellulases for the efficient hydrolysis of lignocellulose [2,3]. Kumar and Wyman [4] reported increased efficiency of cellulases on lignocellulosic biomass after addition of endo-xylanase and $\beta$-xylosidase. $\beta$-xylosidase degrades xylose oligomers before or during enzymatic hydrolysis of lignocellulosic biomass to reduce inhibition on cellulases by xylose oligomers. But under industrial processes, xylose could accumulate to levels that strongly inhibit performance of the catalyst. To overcome this limitation, a xylose-tolerant xylosidase is desirable which can resist high concentrations of the xylose [5,6]. A number of thermostable $\beta$-xylosidases are reported from thermophilic and hyperthermophilic bacteria including species of the genera Geobacillus, Thermoanaerobacter, Thermatoga, and Thermoanaerobacterium [5,7-11]. The thermostable 
enzymes are of interest in industrial processes due to their long shelf lives, compatibility with heat pretreatment, decreased microbial contamination at high temperatures and activity for longer durations [12].

The bacterial $\beta$-D-xylosidases mainly belong to glycosyl hydrolase families GH 3, 30, 39, 43, 52, and 54. Family 39 enzymes belong to the largest glycoside hydrolase clan (GH-A), whose members share a TIM-barrel $(\beta / \alpha)_{8}$ structure and a conserved catalytic machinery [13]. Reports on characterization of GH39 family $\beta$-xylosidases from thermophilic microorganisms are scarce. In this study, we report the cloning and characterization of GH39 thermostable $\beta$-xylosidase from Geobacillus sp. strain WSUCF1. This strain was isolated from samples collected from a compost facility and is an aerobic spore forming thermophile [14].

\section{Results}

\section{Phylogenetic analysis of WSUCF1 $\beta$-xylosidase}

Genome sequence of WSUCF1 revealed several genes encoding glycoside hydrolases. Out of 865 ORFs for carbohydrate metabolism, 70 ORFs were found to be involved in polysaccharide degradation [15]. It was found that the WSUCF1 genome contained two genes coding for putative $\beta$-xylosidases - WP_020755811 (1509 bp) and WP_02075 5806 (2157 bp). The deduced amino acid sequence analysis of these two $\beta$-xylosidases using Pfam showed homology with that of the GH39 and GH52 family, respectively. Literature shows that there is only one report [8] on the cloning and characterization of a GH39 family $\beta$-xylosidase from
Geobacillus spp. Therefore, the WP_020755811 $\beta$-xylosidase was selected for further study.

Figure 1 shows the phylogenetic comparison of the putative WSUCF1 $\beta$-xylosidase amino acid sequence to other $\beta$-xylosidases. It shows that the WSUCF1 enzyme clusters with other GH39 family $\beta$-xylosidases. Within the GH39 group, $\beta$-xylosidase from WSUCF1 formed sister clades supported by high bootstrap values with sequences belonging to Geobacillus spp. (ABI49941, YP_003253769, and ZP_03147822). $\beta$-xylosidases from different GH families (e.g., GH3, GH43, and GH52) made separate clusters on the phylogenetic tree (Figure 1).

Alignment of the amino acid sequences of WSUCF1 $\beta$ xylosidase (WP_020755811) revealed 98, 95, and 91\% identity with GH39 $\beta$-xylosidases from Geobacillus stearothermophilus strain T-6 (ABI49941), Geobacillus sp. Y412MC61 (YP_003253769), and Geobacillus sp. G11M C16 (ZP_03147822), respectively. $\beta$-xylosidase from Geobacillus thermoleovorans (DQ345777) belonging to GH43 family and Geobacillus stearothermophilus (ABI49956) belonging to GH52 family showed only 29 and 33\% identity respectively.

\section{Expression, purification, and characterization of WSUCF1 $\beta$-xylosidase}

For functional analysis, the gene encoding WP_020755811 $\beta$-xylosidase was amplified from the Geobacillus sp. strain WSUCF1 genome. The gene was cloned in the $\mathrm{pRham}^{\mathrm{m}}$ $\mathrm{N}$-His SUMO Kan vector, expressed in E. coli, and purified using Ni-NTA affinity chromatography. SDS-PAGE

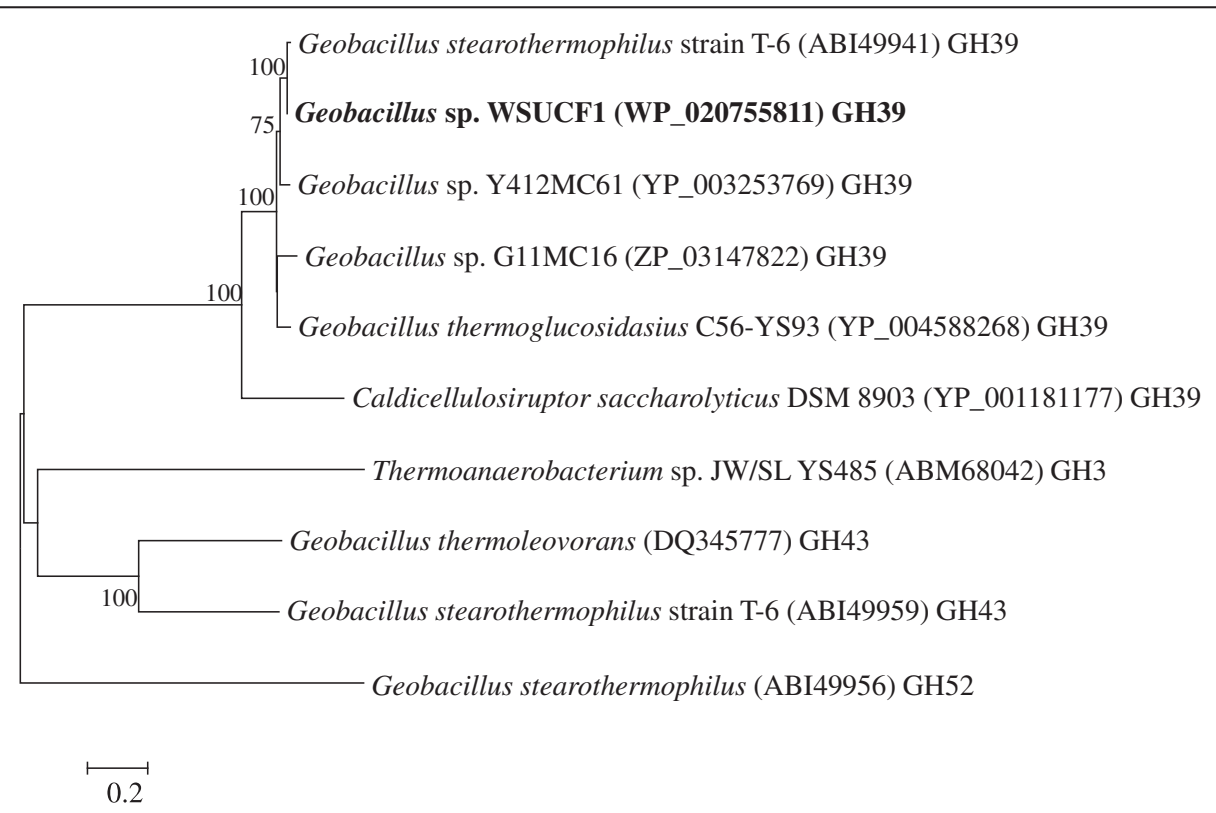

Figure 1 Phylogenetic tree showing relationship between $\beta$-xylosidase sequence of $G$. sp. strain WSUCF1 and reference $\beta$-xylosidase sequences in GenBank, constructed using neighbor-joining method. Bootstrap values which were $\geq 75 \%$ are indicated at the nodes. The scale bar represents 0.2 substitutions per amino acid position. Short title: Phylogenetic relationship between WSUCF1 $\beta$-xylosidase and reference $\beta$-xylosidase sequences. 
analysis of the purified $\beta$-xylosidase showed a prominent band of $58 \mathrm{kDa}$ (Figure 2, Lane 2) which was consistent with the predicted mass of the $\beta$-xylosidase enzyme. No enzyme activity was detected by zymogram analysis of the $58 \mathrm{kDa}$ protein. By omitting the heat treatment prior to electrophoresis, the apparent mass of the prominent protein increased to $230 \mathrm{kDa}$, which displayed $\beta$-xylosidase activity in zymogram analysis (Figure 2, Lanes 3 and 5).

The recombinant $\beta$-xylosidase from WSUCF1 exhibited activity in a broad range of $\mathrm{pH}(4.0-9.5)$ with optima at 6.5 (Figure $3 \mathrm{~A}) . \beta$-xylosidase activity increased linearly when $\mathrm{pH}$ was increased from 4 to 6.5 , but decreased when $\mathrm{pH}$ was further increased from 6.5 to 10. It retained more than $80 \%$ activity in the $\mathrm{pH}$ range of $5.5-7$. At high $\mathrm{pH}$ of 8.6 and 9 (glycine- $\mathrm{NaOH}$ buffer), it retained 62 and $46 \%$ relative activity respectively. Effect of different temperatures on WSUCF1 xylosidase activity is shown in Figure 3B. It exhibited maximum activity at temperature of $70^{\circ} \mathrm{C}$. The enzyme was active between temperatures of 50 to $75^{\circ} \mathrm{C}$, with more than $50 \%$ relative activity.

WSUCF1 $\beta$-xylosidase was highly thermostable in the range of $50-70^{\circ} \mathrm{C}$ (Figure 4). The enzyme was optimally stable at $50^{\circ} \mathrm{C}$ for 1 day without any loss of activity while about $93 \%$ activity was retained after incubation for 9 days. At $60^{\circ} \mathrm{C}$, about $99 \%$ residual activity was detectable after 1 day of incubation and it lost only $17 \%$ of its original activity after incubation for 9 days. The enzyme retained

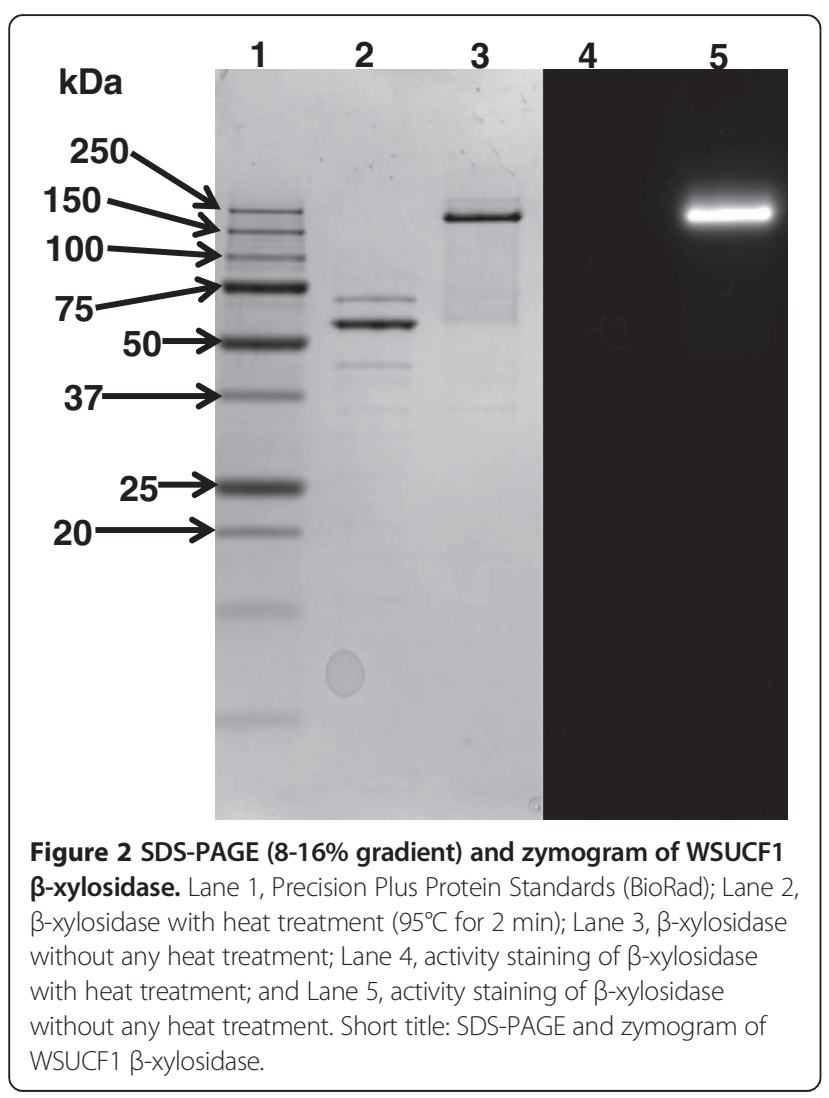

$94 \%$ of its original activity after incubation of 1 day at $70^{\circ}$ $\mathrm{C}$, with a half-life of 9 days. The effect of the presence of metal ions on enzyme activity was studied (Table 1). WSUCF1 $\beta$-xylosidase retained its activity in the presence of different metal ions except $\mathrm{Cu}^{2+}$ and $\mathrm{Hg}^{2+}$. More than $70 \%$ activity was retained in the presence of $\mathrm{Zn}^{2+}, \mathrm{Co}^{2+}$, $\mathrm{Ni}^{2+}, \mathrm{Ca}^{2+}, \mathrm{Mn}^{2+}$, and $\mathrm{Mg}^{2+}$ whereas it lost 73 and $100 \%$ activity in the presence of $\mathrm{Cu}^{2+}$ and $\mathrm{Hg}^{2+}$, respectively.

The kinetic parameters were calculated from LineweaverBurke plots of specific activities at various substrate concentrations (data not shown). The $\mathrm{K}_{\mathrm{m}}$ and $\mathrm{V}_{\max }$ values for WSUCF1 $\beta$-xylosidase with paranitrophenyl- beta-xylopyranoside (pNP-X) were $2.38 \mathrm{mM}$ and $147.0 \mathrm{U} / \mathrm{mg}$, respectively. The substrate specificity of the purified WSUCF1 $\beta$-xylosidase was determined using various substrates. WSUCF1 $\beta$-xylosidase was highly active on p-nitrophenyl $\beta$-D-xylopyranoside (pNPX). No specificity was observed for other p-NP substrates such as p-nitrophenyl $\beta$-D-cellobioside, p-nitrophenyl $\alpha$-D-xylopyranoside, p-nitrophenyl $\alpha$-L-arabinofuranoside, and $\mathrm{p}$-nitrophenyl $\beta$-D-glucopyranoside (data not shown). In addition, polysaccharides such as oat-spelt xylan, beechwood xylan, and birchwood xylan did not serve as substrates for WSUCF1 $\beta$-xylosidase.

Effect of various xylose concentrations on WSUCF1 $\beta$ xylosidase activity was investigated. Results showed that concentrations of up to $50 \mathrm{mM}$ xylose did not have much inhibitory effect. The enzyme retained 85 and $66 \%$ of its activity with 50 and $210 \mathrm{mM}$ xylose concentrations, respectively (Figure 5). When the xylose concentration was increased to $300 \mathrm{mM}$, the enzyme still retained $50 \%$ activity. These data suggest that the WSUCF1 $\beta$-xylosidase is resistant to inhibition from high concentrations of xylose.

\section{Hydrolysis of xylo-oligosaccharides and xylan}

Thin layer chromatography (TLC) results showed that WSUCF1 $\beta$-xylosidase actively hydrolyzed xylooligosaccharides (Figure 6). It was found that enzyme was active on all xylo-oligosaccharides and released xylose and the other xylo-oligosaccharides with a degree of polymerization 1 unit smaller than the substrate. For example, after 2 hours of hydrolysis, most of the xylotetraose was converted into smaller units with increase in xylose concentration. In case of xylopentaose hydrolysis, after 6 hours xylotetraose, xylotriose, xylobiose, and xylose were detected. With increase in time of hydrolysis of xylo-oligosaccharides from 2 to 6 hours, xylose yields were increased (Figure 6).

Mixtures of recombinant WSUCF1 endo-xylanase [16] and WSUCF1 $\beta$-xylosidase were utilized to hydrolyze birchwood xylan. It was interesting to note that endo-xylanase alone produced different concentrations of oligosaccharides (xylobiose, xylotriose and xylotetraose), but after addition of $\beta$-xylosidase, most of these xylo-oligosaccharides were 

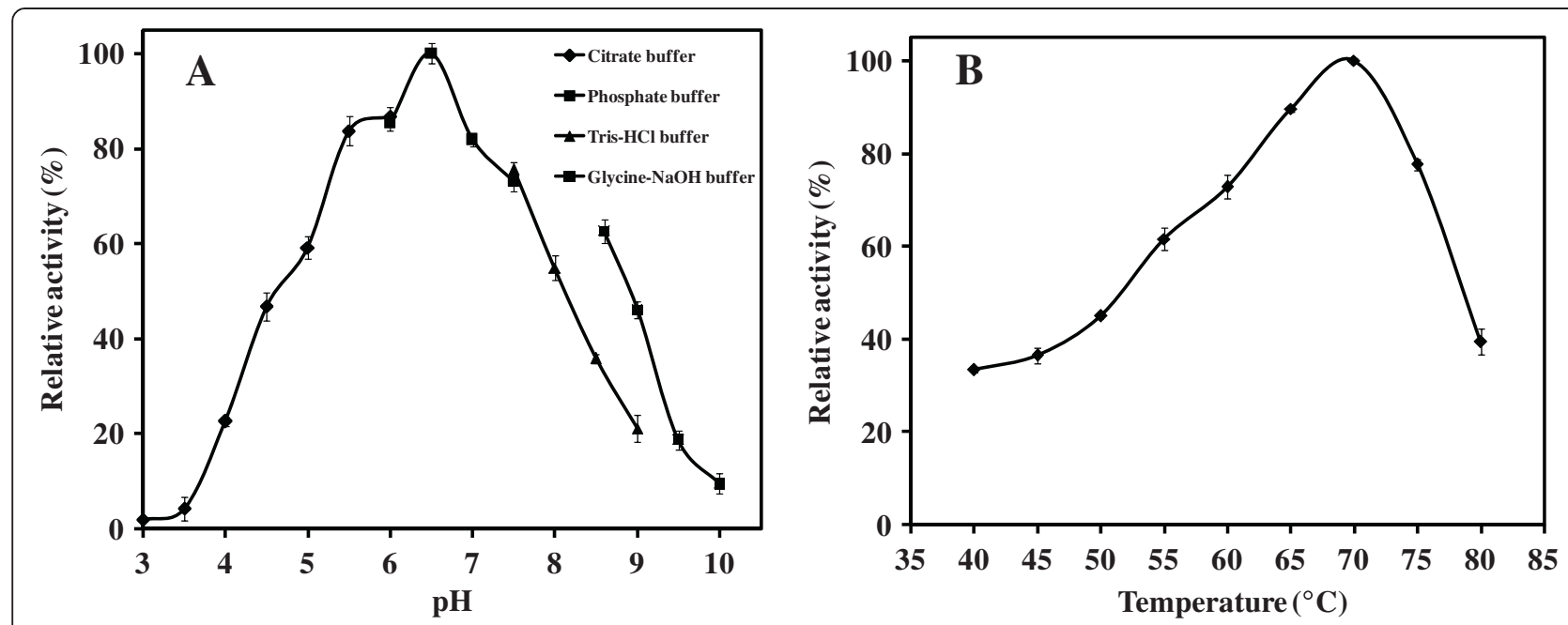

Figure $\mathbf{3}$ Impact of $\mathbf{p H}(\mathbf{A})$ and temperature (B) on the WSUCF1 $\boldsymbol{\beta}$-xylosidase activity. The enzyme activities are expressed as percentages of the maximum activity $(125.2 \mathrm{U} / \mathrm{mg}$ ). The points are the averages of triplicates, and error bars indicate \pm standard deviations of the means ( $\mathrm{n}=3$ ). Error bars smaller than the symbols are not shown. Short title: Impact of pH (A) and temperature (B) on the WSUCF1 $\beta$-xylosidase activity.

converted to xylose (Figure 7). Xylan conversion increased with time. Sugar analysis results revealed that mixture of endo-xylanase and $\beta$-xylosidase worked efficiently and converted approximately $90 \%$ of xylan to xylose.

\section{Discussion}

Cellulose and hemicellulose components of lignocellulosic biomass are a renewable source of sugars. The main component of hemicellulose is xylan which can be converted into xylose using an effective enzyme system of endoxylanase and $\beta$-xylosidase. $\beta$-xylosidase is known to be the

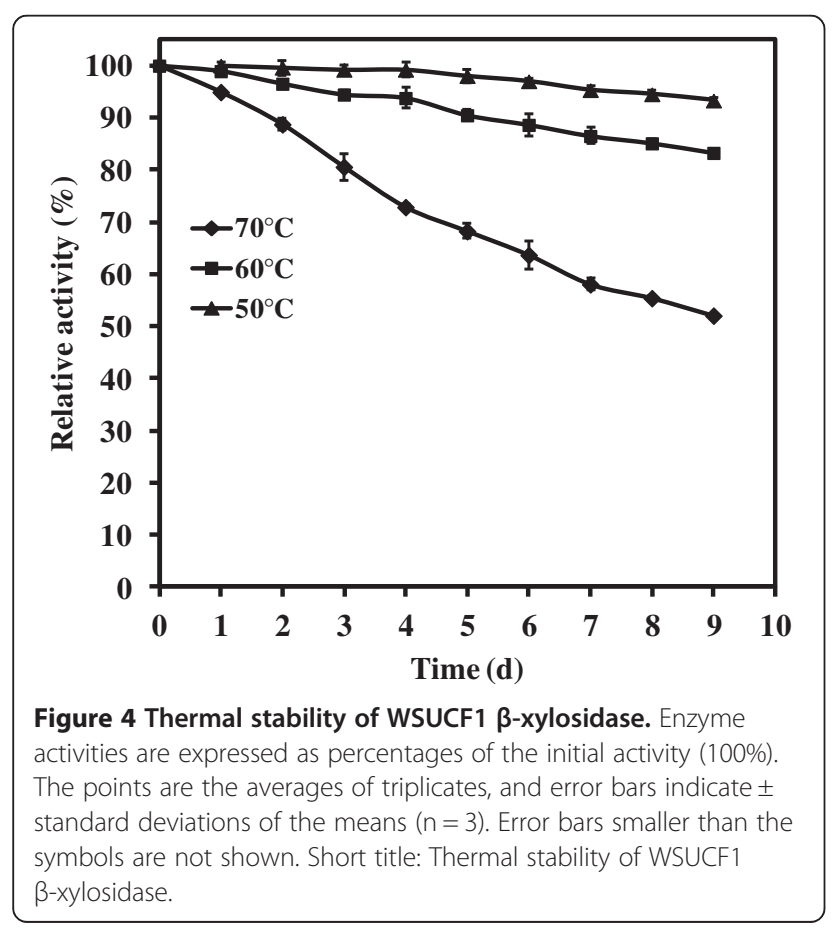

key enzyme for converting xylo-oligosaccharides to xylose. Thermostable $\beta$-xylosidases produced from thermophiles are of importance due to their prolonged activity during the hydrolysis which may allow a reduced dose of enzyme and cost-efficient conversion [17]. Out of various GH families for $\beta$-xylosidase, reports of GH39 family thermostable $\beta$-xylosidases are scarce. To date, most of the reported $\beta$ xylosidases from Geobacillus spp. are from GH52 and GH43 family. For example, $\beta$-xylosidases of Geobacillus thermodenitrificans TSAA1 [7], Geobacillus stearothermophilus [18], Geobacillus pallidus [19], Bacillus stearothermophilus 21 [20] belonged to GH52 family and Geobacillus thermoleovorans IT-08 [21], Geobacillus thermoleovorans IT-08 [22] belonged to GH43 family (Table 2 ).

A high specific activity of $\beta$-xylosidase enzyme for xylooligosaccharides is an important attribute for efficient enzymatic hydrolysis of the hemicellulose component of lignocellulose [2]. WSUCF1 $\beta$-xylosidase specific activity is $133.0 \mathrm{U} / \mathrm{mg}$, which is high in comparison to other

Table 1 Effect of different metal ions on $\beta$-xylosidase activity

\begin{tabular}{lr}
\hline Metal ions & Relative activity (\%) \\
\hline Control & $100.00 \pm 2.69$ \\
$\mathrm{Mn}^{2+}$ & $101.18 \pm 2.32$ \\
$\mathrm{Ca}^{2+}$ & $96.04 \pm 0.95$ \\
$\mathrm{Mg}^{2+}$ & $91.33 \pm 2.97$ \\
$\mathrm{Co}^{2+}$ & $84.69 \pm 3.20$ \\
$\mathrm{Ni}^{2+}$ & $73.17 \pm 2.95$ \\
$\mathrm{Cu}^{2+}$ & $27.79 \pm 1.23$ \\
$\mathrm{Zn}^{2+}$ & $74.71 \pm 2.37$ \\
$\mathrm{Hg}^{2+}$ & 0 \\
\hline
\end{tabular}




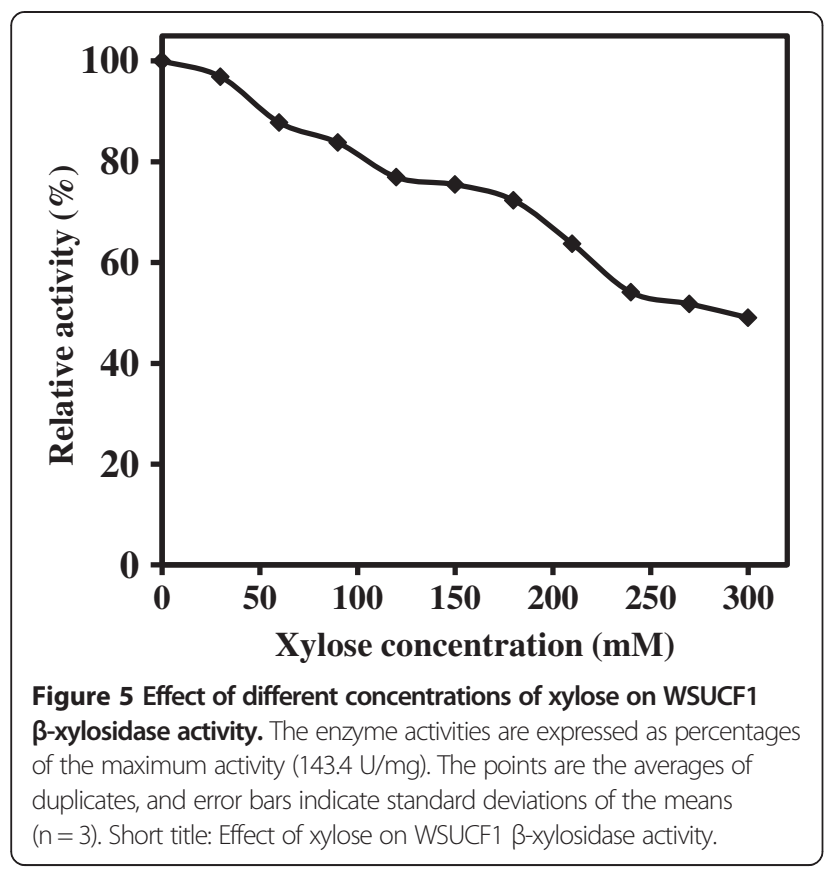

bacterial $\beta$-xylosidases such as Thermoanaerobacterium saccharolyticum JW/SL-YS485 [5], Geobacillus thermoleovorans IT-08 [21], G. thermodenitrificans TSAA1 [7] and G. pallidus [19] that showed specific activity of 45.8, 48.4, 68 and $4.75 \mathrm{U} / \mathrm{mg}$ respectively. Specific activity was also higher than the $\beta$-xylosidases reported from fungal sources Paecilomyces thermophila - 43.4 $\mathrm{U} \mathrm{mg}^{-1}$ [6]; Aspergillus awamori $\mathrm{X}-100-4.2 \mathrm{U} \mathrm{mg}^{-1}[24]$ and commercial enzymes like CAZyme ${ }^{\mathrm{Tm}}$ Xylosidase 1 from Lucigen $-31 \mathrm{U} \mathrm{mg}^{-1}$.

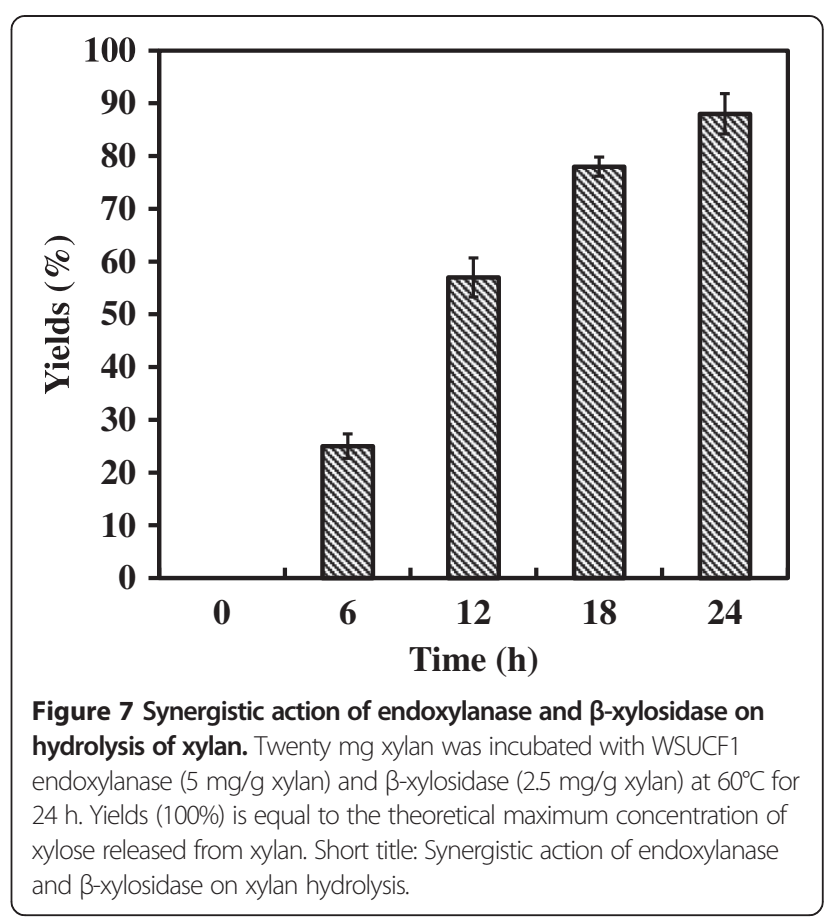

Omitting heat denaturation prior to SDS-PAGE resulted in an increase in the apparent mass of the $\beta$ xylosidase from $58 \mathrm{kDa}$ to $230 \mathrm{kDa}$. Interestingly, only the $230 \mathrm{kDa}$ protein displayed xylosidase activity in the zymogram. This suggests that the WSUCF1 $\beta$-xylosidase is resistant to full denaturation by the detergent alone, and retains at least some of its quaternary structure which is necessary for successful recovery of catalytic activity following SDS-PAGE. Based on the 4-fold increase

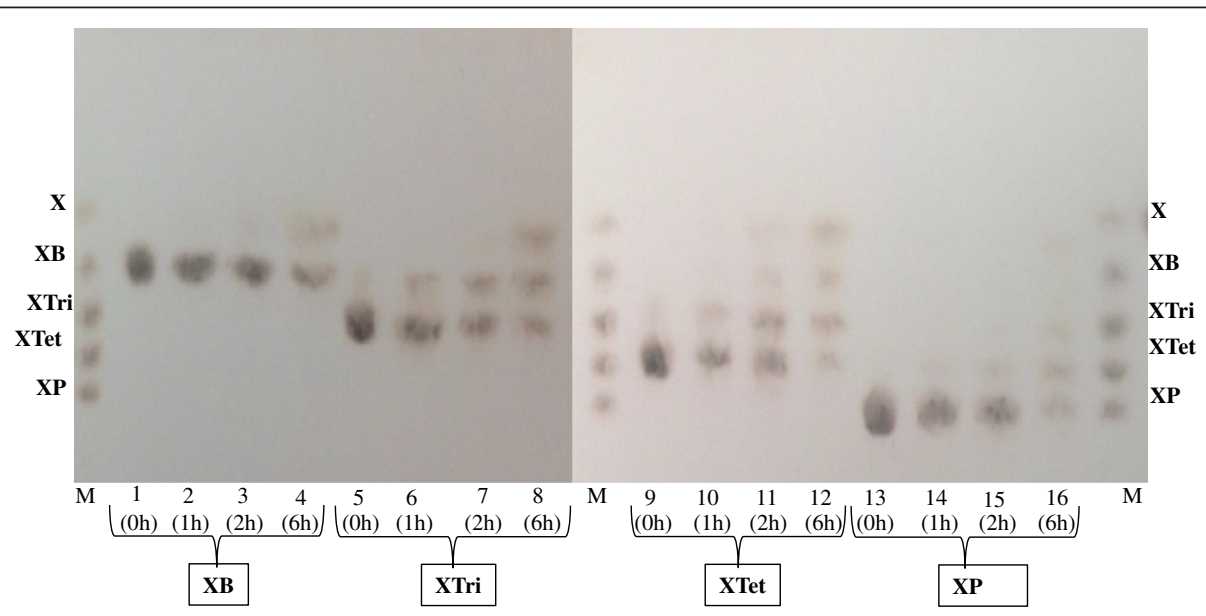

Figure 6 Thin layer chromatography of hydrolysis of xylooligosaccharides. Lane M, mixture of xylooligosaccharides (xylose (X), xylobiose (XB), xylotriose (XTri) and xylotetraose (Xtet), xylopentaose (XP) (1.5\% each, wt/vol). Lane 1, Lane 5, Lane 9, Lane 13 - XB, XT, XTet, XP, respectively (Controls without enzyme); Lane 2-4, Lane 6-8, Lane 10-12, Lane 14-16- XB, XT, XTet, XP (4 $\mu 1,1.5 \%$, wt/vol) each sugar was incubated with WSUCF1 $\beta$-xylosidase $(0.05 \mathrm{U})$ for 1 h, 2 h, 6 h respectively. Short title: Thin layer chromatography of hydrolysis of xylooligosaccharides. 
Table 2 Properties of thermostable $\beta$-xylosidases from thermophiles

\begin{tabular}{|c|c|c|c|c|c|c|c|}
\hline Organism & $\begin{array}{l}\text { GH } \\
\text { family }\end{array}$ & $\begin{array}{l}\text { Optimum } \\
\text { pH }\end{array}$ & $\begin{array}{l}\text { Optimum } \\
\text { temperature }\left({ }^{\circ} \mathrm{C}\right)\end{array}$ & Thermal stability & $\begin{array}{l}\mathrm{K}_{\mathrm{m}} \\
(\mathrm{mM})\end{array}$ & $\begin{array}{l}V_{\max } \\
(\mathrm{U} / \mathrm{mg})\end{array}$ & References \\
\hline Geobacillus sp. WSUCF1 & 39 & 6.5 & 70 & Half-life of 9 days at $70^{\circ} \mathrm{C}$ & 2.3 & 147 & This study \\
\hline $\begin{array}{l}\text { Thermoanaerobacterium } \\
\text { saccharolyticum JW/SL-YS485 }\end{array}$ & Novel & 6.0 & 65 & Half-life of $1 \mathrm{~h}$ at $67^{\circ} \mathrm{C}$ & 28.0 & 276 & {$[5]$} \\
\hline Geobacillus thermodenitrificans TSAA1 & 52 & 7.0 & 60 & Half-life of $3 \mathrm{~h}$ at $70^{\circ} \mathrm{C}$ & 2.8 & 4.16 & [7] \\
\hline Geobacillus stearothermophilus & 52 & 6.5 & 70 & Half-life of $3.4 \mathrm{~h}$ at $70^{\circ} \mathrm{C}$ & 0.15 & NA & [18] \\
\hline Bacillus stearothermophilus & NA & 6.0 & 70 & Half-life of approx. $1 \mathrm{~h}$ at $70^{\circ} \mathrm{C}$ & 1.2 & NA & [10] \\
\hline Bacillus thermantarcticus & NA & 6.0 & 70 & Stable for $1 \mathrm{~h}$ at $60^{\circ} \mathrm{C}$ & 0.5 & NA & [23] \\
\hline Geobacillus pallidus & 52 & 8.0 & 70 & Half-life of approx. $10 \mathrm{~h}$ at $70^{\circ} \mathrm{C}$ & 2.4 & 4.72 & [19] \\
\hline Geobacillus thermoleovorans IT-08 & 43 & 6.0 & 60 & $\begin{array}{l}\text { Retained more than } 70 \% \text { activity } \\
\text { after } 1 \mathrm{~h} \text { at } 70^{\circ} \mathrm{C}\end{array}$ & 0.06 & NA & [21] \\
\hline Geobacillus thermoleovorans IT-08 & 43 & 5.0 & NA & Half-life of $35 \mathrm{~min}$ at $57.5^{\circ} \mathrm{C}$ & 0.55 & NA & [22] \\
\hline
\end{tabular}

in apparent mass, it appears that that the WSUCF1 $\beta$ xylosidase exists in tetrameric form. GH39 $\beta$-xylosidase from Thermoanaerobacterium sp. has been reported to exist as a tetramer $[1,25]$. Property of retaining its activity in the presence of detergent could make it suitable for commercial applications in need for xylosidases resistant to denaturation with detergents.

WSUCF1 $\beta$-xylosidase was active across a broad $\mathrm{pH}$ range of 4.5-9.5 with maximum activity at $\mathrm{pH} 6.5$. $\beta$-xylosidase from Geobacillus stearothermophilus T-6 also exhibited maximum activity at 6.5 [26] whereas $\beta$-xylosidases from Geobacillus thermoleovorans IT-08 [21], Geobacillus thermodenitrificans TSAA1 [7] and G. pallidus [19] showed their $\mathrm{pH}$ optima at 6.0, 7.0 and 8.0, respectively. Activity at broad $\mathrm{pH}$ range is a critical feature of applicability of industrial enzymes. $\beta$-xylosidases from other reported Geobacillus spp. had a narrow $\mathrm{pH}$ range except G. pallidus [19]. At pH 9.0, less than $10 \%$ and $40 \%$ relative activity for Geobacillus thermoleovorans IT-08 [21] and Geobacillus thermodenitrificans TSAA1 [7], respectively compared to 46\% from WSUCF1 $\beta$-xylosidase whereas G. pallidus [19] retained 89\% activity.

WSUCF1 $\beta$-xylosidase was also active across a broad temperature range with optima at $70^{\circ} \mathrm{C}$. Temperature optima was higher than Geobacillus stearothermophilus T-6 $\left(65^{\circ} \mathrm{C},[26]\right)$, Geobacillus thermoleovorans IT-08 $\left(65^{\circ}\right.$ C, [21]), Geobacillus thermodenitrificans TSAA1 $\left(60^{\circ} \mathrm{C}\right.$, [7]), and Thermoanaerobacterium saccharolyticum JW/ SL-YS485 $\left(65^{\circ} \mathrm{C},[5]\right)$. At a temperature higher than its optima (i.e. at $75^{\circ} \mathrm{C}$ ), WSUCF1 $\beta$-xylosidase retained $77 \%$ relative activity which was comparable to relative activities from Geobacillus thermodenitrificans TSAA1 [7] and G. pallidus [19]. Geobacillus thermoleovorans IT-08 [21] $\beta$-xylosidase retained less than $40 \%$ relative activity at $75^{\circ} \mathrm{C}$.

The performance of an enzyme mainly depends upon its operational stability. Enzymatic hydrolysis of lignocellulosic biomass is usually carried out for $\geq 3$ days, so there is utmost requirement of enzymes which could retain their stability during this period. Therefore, thermostable enzymes are gaining wide industrial and biotechnological interest due to their ability to withstand the often relatively harsh conditions of industrial processing [27]. WSUCF1 $\beta$-xylosidase was found to be highly thermostable when compared with other reported $\beta$-xylosidases from thermophiles. WSUCF1 xylosidase retained 93, 83 and $50 \%$ activity at 50,60 and $70^{\circ} \mathrm{C}$ after the period of 9 days. $\beta$-xylosidase from Geobacillus pallidus [19] had a half-life of $50 \mathrm{~h}$ at $60^{\circ} \mathrm{C}$, Bacillus halodurans XylBH39 and $\mathrm{XylBH} 43$ displayed approximate half-life values of 2.40 and $0.05 \mathrm{~h}$, respectively at $60^{\circ} \mathrm{C}$, Geobacillus thermoleovorans IT-08 [21] retained more than 70\% activity after $1 \mathrm{~h}$, Thermoanaerobacterium saccharolyticum JW/SL-YS485 [5] exhibited half-life of $1 \mathrm{~h}$ at $67^{\circ} \mathrm{C}$, Geobacillus thermoleovorans IT-08 [22] retained 50\% activity after $35 \mathrm{~min}$ at $57.5^{\circ} \mathrm{C}$. At $50^{\circ} \mathrm{C}$, the WSUCF $1 \beta$-xylosidase retained almost $100 \%$ relative activity, and therefore this enzyme could be used as a component of commercial enzyme cocktails mainly working optimally at $\leq 50^{\circ} \mathrm{C}$. Various studies have also been published to enhance thermal stability of xylanases using genetic engineering [28,29] whereas WSUCF1 $\beta$-xylosidase is highly thermostable in its native form. Thus $\beta$-xylosidase from Geobacillus sp. WSUCF1 appears to be among the most thermostable $\beta$ xylosidases from thermophiles having optimum growth temperatures of $\leq 70^{\circ} \mathrm{C}$ reported to date (Table 2). Higher thermal-stability of WSUCF1 $\beta$-xylosidase will allow hydrolysis for extended times to convert lignocellulosic biomass into sugars, leading to decreased amount of enzyme needed for saccharification. It has also been stated that enzymes are the main cost in lignocellulosic conversion process [30]. Due to high thermostability of WSUCF1 $\beta$ xylosidase, it could be recycled with its full activity for the subsequent enzymatic hydrolysis. Several studies have been reported on enzyme recycling, which significantly 
reduce overall cost of the process $[31,32]$. These discussions showed that thermostability is an essential attribute of an enzyme for its commercial application.

The kinetic properties of WSUCF1 $\beta$-xylosidase $\left(\mathrm{K}_{\mathrm{m}}\right.$ $2.38 \mathrm{mM}$ and $\mathrm{V}_{\max }-147.0 \mathrm{U} / \mathrm{mg}$ ) were significantly different from those of the other reported $\beta$-xylosidases. Compared to WSUCF1 $\beta$-xylosidase, Thermoanaerobacterium saccharolyticum JW/SL-YS485 $\beta$-xylosidase [5] and Geobacillus thermodenitrificans TSAA1 $\beta$-xylosidase [7] showed higher $K_{m}$ of $28 \mathrm{mM}$ and $2.8 \mathrm{mM}$, respectively, which shows WSUCF1 $\beta$-xylosidase has more specificity towards substrate.

$\beta$-xylosidase plays a vital role in the conversion of xylobiose and other higher xylo-oligosaccharides to xylose during enzymatic hydrolysis [1]. At commercial scale, performing enzymatic hydrolysis of lignocellulosic biomass at high solid loadings is beneficial as it increases product concentrations and utilize less water. On the other end, this increased product concentrations could lead to enzyme inhibition called end-product inhibition [33]. Therefore for industrial processes, utilization of a xylose tolerant $\beta$-xylosidase is very important in order to achieve high concentrations of xylose by avoiding end product inhibition. WSUCF1 $\beta$-xylosidase exhibited tolerance to high concentrations of xylose, retaining $80 \%$ of initial activity at $100 \mathrm{mM}$ xylose i.e. higher tolerance than $\beta$-xylosidase from Paecilomyces thermophila which retained only $54 \%$ activity in the presence of $100 \mathrm{mM}$ xylose. The other $\beta$-xylosidases reported for exhibiting strong tolerance to xylose inhibition are from Scytalidium thermophilum ([34] and Thermatoga thermarum [11] which were insensitive to inhibition by up to $200 \mathrm{mM}$ xylose.

Complete enzymatic degradation of xylan to xylose is one of the most important and challenging reactions. Endoxylanases are reported to deconstruct the xylan into xylose and different xylo-oligosaccharides. These xylo-oligosaccharides are often found in hydrolysates of lignocellulosic materials as they can't be fermented by ethanalogens leading to lower yields of ethanol [35]. Kont et al. [36] demonstrated that xylo-oligosaccharides are also one of the strong inhibitors of cellulases. Zhang and Viikari [37] and Qing et al. [38] also studied the inhibitory effects of xylo-oligosaccharides on cellobiohydrolase. These studies demonstrate the necessity of enzymes which could breakdown these inhibitory xylo-oligosaccharides to obtain better fermentable sugar yields. Xylo-oligosaccharides are reported to be hydrolyzed to xylose by exo-type xylanolytic $\beta$-xylosidase [39]. WSUCF1 $\beta$-xylosidase released xylose from all the tested xylo-oligosaccharides (X2-X5) indicating that it is a true $\beta$ D-xylosidase [34]. Addition of thermostable WSUCF1 $\beta$-xylosidase along with endo-xylanase during birchwood xylan hydrolysis increased final xylose yields to approximately $90 \%$ which would further improve the fermentation product yields. Similar observations were observed in $\beta$ xylosidases from Paecilomyces thermophila [6] and Thermotoga thermarum [11], which were active on different xylo-oligosaccharides obtained after xylan hydrolysis.

\section{Conclusions}

In this study, a GH39 $\beta$-xylosidase from the thermophile Geobacillus sp. strain WSUCF1 was cloned and purified. Compared to $\beta$-xylosidases from other thermophiles, WSUCF1 $\beta$-xylosidase showed more thermostability. It also displayed various other desirable properties including high specific activity, high xylose tolerance, excellent hydrolytic activity on p-nitrophenyl-xylopyranoside and xylo-oligosaccharides, and resistance to detergent. A high degree of synergy was found with respect to the release of reducing sugars from xylans when $\beta$-xylosidase was combined with the endo-xylanase. These findings open a path to potential industrial applications of the WSUCF1 $\beta$-xylosidase.

\section{Methods}

Multiple sequence alignment and phylogenetic analysis

Nucleotide sequence from the whole genome of Geobacillus sp. strain WSUCF1 [15] was translated to amino acid sequence using ExPASy-Translate tool (http://web. expasy.org/translate/). Amino acid sequence of Geobacillus sp. strain WSUCF1 $\beta$-xylosidase was used as a BLAST query for seeking other homologous amino acid sequences. The sequence alignment was created with ClustalW program. Sequences were aligned manually using the Mega 5.2 software. Phylogenetic relationship was inferred using the Neighbor-Joining (NJ) method as described earlier [16].

\section{Cloning and expression of WSUCF1 $\beta$-xylosidase}

To amplify the 1509 bp $\beta$-xylosidase gene sequence from Geobacillus sp. strain WSUCF1 (simply referred to as WSUCF1), PCR primers (F 5'- CGCGAACAGATTG GAGGT AAGGTTGTAAACGTGCCAAGC-3' and R 5'GTGGCGGCCGCTCTATTATGAAGAATA CGATGTCA TTTC-3') containing homologous sequences to the ends of the pRham N-His SUMO Kan Vector (Lucigen, Middleton, WI) (italicized) were designed to amplify the $\beta$-xylosidase gene sequence. PCR product containing the gene of interest is cloned as a fusion to cleavable SUMO (Small Ubiquitin-like Modifier) tag under the control of the L-rhamnose-inducible rhaPBAD promoter harbored on the pRham ${ }^{\text {tw }} \mathrm{N}$-His SUMO Vector. PCR conditions were as follows: initial denaturation at $94^{\circ} \mathrm{C}$ for $2 \mathrm{~min}$ followed by 25 cycles of $94^{\circ} \mathrm{C}$ for $15 \mathrm{sec}, 55^{\circ} \mathrm{C}$ for $15 \mathrm{sec}$ and $72^{\circ} \mathrm{C}$ for $1 \mathrm{~min} 30 \mathrm{sec}$ in $50 \mu \mathrm{l}$ reaction with final extension of $10 \mathrm{~min}$ at $72^{\circ} \mathrm{C}$. The amplicon was cloned into the vector according to the manufacturer's instructions, and the resulting plasmid transformed into E. coli 
chemically competent cells (Lucigen, Middleton, WI). After transformation, E. coli cells were plated on agar plates containing Terrific broth (TB) and $30 \mu \mathrm{g} / \mathrm{ml}$ kanamycin, incubated for 36 hours at $37^{\circ} \mathrm{C}$. The positive clones were screened using colony PCR and confirmed by $\beta$-xylosidase activity assay as described below. Cycling conditions for colony PCR were: initial denaturation $94^{\circ} \mathrm{C}, 5$ sec; 25 cycles of $94^{\circ} \mathrm{C}$ for $15 \mathrm{sec}, 55^{\circ} \mathrm{C}$ for $15 \mathrm{sec}$ and $72^{\circ} \mathrm{C}$ for $1 \mathrm{~min}$; extension $72^{\circ} \mathrm{C} 10 \mathrm{~min}$.

\section{Purification of the recombinant $\beta$-xylosidase}

A positive clone was grown in $250-\mathrm{mL}$ flask containing $50 \mathrm{ml}$ Terrific broth (TB), kanamycin $(30 \mu \mathrm{g} / \mathrm{ml})$, and the expression of $\beta$-xylosidase was induced by addition of $0.2 \%$ rhamnose followed by incubation at $37^{\circ} \mathrm{C}$ for 48 hours. Cells were centrifuged at 10,000 rpm for 15 minutes. Ten $\mathrm{ml}$ of clear culture supernatant was applied to a Ni-NTA agarose resin column $(1.5 \mathrm{~cm} \times 5 \mathrm{~cm})$ equilibrated with equilibration buffer $\left(50 \mathrm{mM} \mathrm{NaH}_{2} \mathrm{PO}_{4}, 300 \mathrm{mM} \mathrm{NaCl}, 10 \mathrm{mM}\right.$ imidazole, $\mathrm{pH}$ 8.0). After binding, the column was washed with wash buffer ( $50 \mathrm{mM} \mathrm{NaH}_{2} \mathrm{PO}_{4}, 300 \mathrm{mM} \mathrm{NaCl}, 20 \mathrm{mM}$ imidazole, $\mathrm{pH}$ 8). The bound enzyme was eluted with elution buffer $\left(50 \mathrm{mM} \mathrm{NaH} \mathrm{PO}_{4}, 300 \mathrm{mM} \mathrm{NaCl}, 250 \mathrm{mM}\right.$ imidazole, $\mathrm{pH}$ 8.0) at a flow rate of $0.5 \mathrm{ml} / \mathrm{min}$ collecting $1 \mathrm{ml}$ fractions. Fractions containing $\beta$-xylosidase activity were pooled. To remove the His tag from the protein, the protein was cleaved with SUMO specific protease which also contains the His tag (as per manufacturer's protocol). After the cleavage, the protein was separated from the SUMO protease and the His tag by re-performing metal affinity chromatography with Ni-NTA agarose resin column. His tag and SUMO protease bound to the resin while the protein was eluted. The homogeneity of the purified enzyme was checked by sodium dodecyl sulfate-polyacrylamide gel electrophoresis (SDS-PAGE) as described below. Protein concentrations in the samples were determined using 2-D Quant kit (GE Healthcare).

\section{Assay of $\beta$-xylosidase activity}

For $\beta$-xylosidase activity, pNPX, $2.5 \mathrm{mg} / \mathrm{mL}$ was used as a substrate. The assay mixture contained $80 \mu \mathrm{L}$ of substrate, $100 \mu \mathrm{l} 0.1 \mathrm{M}$ phosphate buffer (pH 6.5), and $20 \mu \mathrm{L}$ of appropriately diluted enzyme. The reaction was carried out at $70^{\circ} \mathrm{C}$ for $10 \mathrm{~min}$ and then stopped by the addition of $100 \mu \mathrm{L}$ of sodium carbonate $(2 \% \mathrm{w} / \mathrm{v})$. The $\mathrm{p}$-nitrophenol released was determined by measuring the absorbance of each sample at $410 \mathrm{~nm}$. One unit of enzyme activity was defined as the amount of enzyme that released $1 \mu \mathrm{mol}$ of p-NP per minute under the standard assay conditions.

\section{SDS-PAGE, zymography, and molecular mass} determination

SDS-PAGE was performed as described by Laemmli (1970) [40]. The molecular weight standards used were
BioRad Precision plus standards. To obtain zymogram of $\beta$-xylosidase activity, enzyme (10 $\mu \mathrm{l})$ was mixed with $10 \mu \mathrm{l} 2 \mathrm{X}$ SDS sample buffer. Two different processing conditions were used prior to loading: i) purified enzyme sample was heated to $95^{\circ} \mathrm{C}$ for $2 \mathrm{~min}$ and then loaded to an $8-16 \%$ gradient SDS-PAGE gel and ii) enzyme sample was loaded directly to an $8-16 \%$ gradient SDS-PAGE gel without any heating. Current was passed through the gel (150 V constant voltage) for about $1 \mathrm{~h}$ until the bromophenol blue dye-front migrated to the bottom of the gel. The gel was washed successively with the following for 30 minutes each: $20 \%$ isopropanol in phosphate buffer saline (PBS, $\mathrm{pH}$ 5.9); $8 \mathrm{M}$ urea in PBS; and with PBS (pH 5.9) 3 times. The gel was incubated with substrate $(0.1 \mathrm{mg} / \mathrm{ml}$ 4-methylumbelliferyl- $\beta$-Dxylopyranoside in PBS, pH 5.9) for $30 \mathrm{~min}$. Finally, the detection of $\beta$-xylosidase activity was examined by fluorescence of 4-methylumbelliferone, which is visualized under ultraviolet light. The gel was then stained with Coomassie brilliant blue R-250 (LabSafe GEL Blue, G-Biosciences, St. Louis, MO) to visualize protein.

\section{Characterization of WSUCF1 $\beta$-xylosidase}

Activity profile of $\beta$-xylosidase was determined at different $\mathrm{pH} 3-10$. The enzyme assays were carried in the following discontinuous buffer system under standard assay conditions: $100 \mathrm{mM}$ sodium citrate $(\mathrm{pH} 3-6)$, sodium phosphate $(\mathrm{pH} 6-8)$, Tris- $\mathrm{HCl}(\mathrm{pH} 7.5-9)$, or glycine- $\mathrm{NaOH}$ $(\mathrm{pH} 8.5-10)$. The optimum $\mathrm{pH}$ was used to determine the optimum temperature for the $\beta$-xylosidase. Experiments were carried out in the temperature range of $40-80^{\circ} \mathrm{C}$. In order to assess thermostability of $\beta$-xylosidase, $1 \mathrm{ml}$ of enzyme was incubated at $50-80^{\circ} \mathrm{C}$ for varying time intervals. Subsamples $(20 \mu \mathrm{l})$ were removed at specific time intervals over the period of incubation. The residual enzyme activity was measured and plotted against time. Initial activity was assumed to be $100 \%$ and residual enzyme activity reported as percentages of the initial activity during the incubation period.

Kinetic parameters $\left(\mathrm{K}_{\mathrm{m}}\right.$ and $\left.\mathrm{V}_{\mathrm{max}}\right)$ for the purified recombinant $\beta$-xylosidase were determined by measuring the enzyme activity using $0-15 \mathrm{mM}$ pNP-X as substrate in $50 \mathrm{mM}$ phosphate buffer $(\mathrm{pH} 6.5)$ at $70^{\circ} \mathrm{C}$. The data was plotted according to the Lineweaver-Burk method to calculate $\mathrm{K}_{\mathrm{m}}$ and $\mathrm{V}_{\max }$ values.

Substrate specificity of the purified enzyme was investigated under standard assay conditions as described above. Activities towards p-nitrophenyl derivatives were measured by the rate of p-nitrophenol formed during hydrolysis from $2.5 \mathrm{mg} / \mathrm{ml}$ of the substrates in $50 \mathrm{mM}$ phosphate buffer $\left(\mathrm{pH} \mathrm{6.5)}\right.$ at $70^{\circ} \mathrm{C}$ for $10 \mathrm{~min}$, and detected by spectrophotometry at $410 \mathrm{~nm}$. Substrates used were $\mathrm{p}$-nitrophenyl $\beta$-D-xylopyranoside, $\mathrm{p}$-nitrophenyl $\alpha$-L-arabinofuranoside, $\mathrm{p}$-nitrophenyl $\beta$-D-cellobioside, p-nitrophenyl $\beta$-D-glucopyranoside. 
The effect of metal ions on enzyme activity of $\beta$-xylosidase was determined by adding chloride salts of $\mathrm{Mg}^{2+}, \mathrm{Zn}^{2+}, \mathrm{Ba}^{2+}, \mathrm{Ni}^{2+}, \mathrm{Mn}^{2+}, \mathrm{Ca}^{2+}, \mathrm{Co}^{2+}, \mathrm{Cu}^{2+}$ and $\mathrm{Al}^{3+}$ to the enzyme reaction mixtures at a final concentration of $1 \mathrm{mM}$. The enzyme reaction mixtures were incubated for $10 \mathrm{~min}$ at $70^{\circ} \mathrm{C}$, and then activities were measured as described above. The activity of the enzyme without adding any metal ions was considered as $100 \%$.

The inhibitory effect of different concentrations of xylose was determined by incubating $20 \mu \mathrm{l}$ enzyme solution, $80 \mu \mathrm{l}$ of $2.5 \mathrm{mg} / \mathrm{ml} \mathrm{pNPX} \mathrm{dissolved} \mathrm{in} 100 \mathrm{mM}$ phosphate buffer (pH 6.5) and varying amounts of xylose with a final concentration of $0-300 \mathrm{mM}$ at $70^{\circ} \mathrm{C}$ for $10 \mathrm{~min}$. Residual $\beta$-xylosidase activities were measured as described above.

\section{Hydrolysis of xylo-oligosaccharides by the WSUCF1 $\beta$-xylosidase}

Four $\mu \mathrm{l}$ of $1.5 \%(\mathrm{w} / \mathrm{v})$ xylo-oligosaccharides was incubated with $0.05 \mathrm{U}$ of the $\beta$-xylosidase in $50 \mathrm{mM}$ phosphate buffer $(\mathrm{pH} 6.5)$ at $70^{\circ} \mathrm{C}$ for 1,2 and $6 \mathrm{~h}$. Aliquots were withdrawn at 0,1 , and $2 \mathrm{~h}$, the reactions were stopped by boiling for $5 \mathrm{~min}$. Products of enzymatic hydrolyses were analyzed by spotting on silica gel plates 60 F-254 (E. Merck, Germany). The plates were developed with butanol-acetic acid-water $(2: 1: 1, \mathrm{v} / \mathrm{v} / \mathrm{v})$ solvent system followed by heating for few minutes at $105^{\circ} \mathrm{C}$ in an oven, after spraying the plates with a methanol-sulfuric acid mixture (9:1, v/v) [11]. A mixture of xylo-oligosaccharides consisting of xylose $(\mathrm{X})$, xylobiose (XB), xylotriose (XTri), and xylotetraose (XTet) and xylopentaose (XP) were used as standards.

\section{Synergistic effect of WSUCF1 endo-xylanase and $\beta$-xylosidase on xylan hydrolysis}

For enzymatic hydrolysis of xylan, the reaction mixture containing $5 \mathrm{mg}$ purified recombinant endoxylanase/g xylan (purified enzyme from Geobacillus sp. WSUCF1, [16]), $2.5 \mathrm{mg}$ recombinant $\beta$-xylosidase/g xylan and $20 \mathrm{mg}$ birchwood xylan in $4 \mathrm{ml}$ of $50 \mathrm{mM}$ phosphate buffer (pH 6.5) was incubated at $60^{\circ} \mathrm{C}$ for 6 to $24 \mathrm{~h}$. Xylose, xylobiose, xylotriose and xylotetraose were determined by high performance liquid chromatography using a $30 \mathrm{~mm}$ Micro-Guard Cation $\mathrm{H}$ cartridge and a $300 \mathrm{~mm}$ Aminex HPX-87H column (Bio-Rad Laboratories, Inc., Hercules, CA) on a 1100 Series HPLC system equipped with a refractive index detector (Agilent Technologies, Santa Clara, CA). Samples $(10 \mu \mathrm{l})$ were injected onto a heated column $\left(55^{\circ} \mathrm{C}\right)$ and eluted at $0.6 \mathrm{ml} / \mathrm{min}$ using $5 \mathrm{mM} \mathrm{H}_{2} \mathrm{SO}_{4}$ as mobile phase.

\section{Competing interests}

The authors declare that they have no competing interests.

\section{Authors' contributions}

$A B$ designed and performed the experiments and drafted the manuscript. $\mathrm{KMB}$ helped to analyze the degradation products and revised the manuscript. RKS directed the over-all study and revised the manuscript. All authors have read and approved the final manuscript.

\section{Acknowledgements}

The authors gratefully acknowledge the financial support provided by National Science Foundation - Industry/University Cooperative Research Center (NSF-I/UCRC, Grant \#441087). The support from the Department of Chemical and Biological Engineering at the South Dakota School of Mines and Technology is gratefully acknowledged.

\section{Author details}

'Department of Chemical and Biological Engineering, South Dakota School of Mines and Technology, Rapid City, SD 57701, USA. ${ }^{2}$ Renewable Product Technology Research Unit, Agricultural Research Service, National Center for Agricultural Utilization Research, U.S. Department of Agriculture, Peoria, IL 61604, USA. ${ }^{3}$ Present address: Great Lakes Bioenergy Research Center, Michigan State University, East Lansing, Ml 48824, USA.

Received: 22 August 2014 Accepted: 1 December 2014

Published online: 23 December 2014

\section{References}

1. Juturu V, Wu JC: Microbial xylanases: engineering, production and industrial applications. Biotechnol Adv 2012, 30:1219-1227.

2. Yeoman CJ, Han Y, Dodd D, Schroeder CM, Mackie RI, Cann IK: Thermostable enzymes as biocatalysts in the biofuel industry. Adv Appl Microbiol 2010, 70:1-55.

3. Gao D, Uppugundla N, Chundawat SP, Yu X, Hermanson S, Gowda K, Brumm P, Mead D, Balan V, Dale BE: Hemicellulases and auxiliary enzymes for improved conversion of lignocellulosic biomass to monosaccharides. Biotechnol Biofuels 2011, 4:5.

4. Kumar R, Wyman C: Enzymatic hydrolysis of cellulosic biomass through enhanced removal of oligomers. 2010. WO2010011957A2.

5. Shao W, Xue Y, Wu A, Kataeva I, Pei J, Wu H, Wiegel J: Characterization of a novel beta-xylosidase, XylC, from Thermoanaerobacterium saccharolyticum JW/SL-YS485. Appl Environ Microbiol 2011, 77:719-726.

6. Yan QJ, Wang L, Jiang ZQ, Yang SQ, Zhu HF, Li LT: A xylose-tolerant beta-xylosidase from Paecilomyces thermophila: characterization and its co-action with the endogenous xylanase. Bioresour Technol 2008, 99:5402-5410.

7. Anand A, Kumar V, Satyanarayana T: Characteristics of thermostable endoxylanase and $\beta$-xylosidase of the extremely thermophilic bacterium Geobacillus thermodenitrificans TSAA1 and its applicability in generating xylooligosaccharides and xylose from agro-residues. Extremophiles 2013, 17:357-366

8. Bravman T, Mechaly A, Shulami S, Belakhov V, Baasov T, Shoham G, Shoham Y: Glutamic acid 160 is the acid-base catalyst of beta-xylosidase from Bacillus stearothermophilus T-6: a family 39 glycoside hydrolase. FEBS Lett 2001, 495:115-119.

9. Huang Z, Liu X, Zhang S, Liu Z: GH52 xylosidase from Geobacillus stearothermophilus: characterization and introduction of xylanase activity by site-directed mutagenesis of Tyr509. J Ind Microbiol Biotechnol 2014, 41:65-74.

10. Nanmori T, Watanabe T, Shinke R, Kohno A, Kawamura Y: Purification and properties of thermostable xylanase and beta-xylosidase produced by a newly isolated Bacillus stearothermophilus strain. J Bacteriol 1990, 172:6669-6672.

11. Shi H, Li X, Gu H, Zhang Y, Huang Y, Wang L, Wang F: Biochemical properties of a novel thermostable and highly xylose-tolerant $\beta$-xylosidase/ $\alpha$-arabinosidase from Thermotoga thermarum. Biotechnol Biofuels 2013, 6:27.

12. Bhalla A, Bansal N, Kumar S, Bischoff KM, Sani RK: Improved lignocellulose conversion to biofuels with thermophilic bacteria and thermostable enzymes. Bioresour Technol 2013, 128:751-759.

13. Czjzek M, Ben David A, Bravman T, Shoham G, Henrissat B, Shoham Y: Enzyme-substrate complex structures of a GH39 beta-xylosidase from Geobacillus stearothermophilus. J Mol Biol 2005, 353:838-846.

14. Rastogi G, Bhalla A, Adhikari A, Bischoff KM, Hughes SR, Christopher LP, Sani RK: Characterization of thermostable cellulases produced by Bacillus and Geobacillus strains. Bioresour Technol 2010, 101:8798-8806.

15. Bhalla A, Kainth AS, Sani RK: Draft genome sequence of lignocellulosedegrading thermophilic bacterium Geobacillus sp. strain WSUCF1. Genome Announc 2013, 1:4 
16. Bhalla A, Bischoff KM, Uppugundla N, Balan V, Sani RK: Novel thermostable endo-xylanase cloned and expressed from bacterium Geobacillus sp. WSUCF1. Bioresour Technol 2014, 165:314-318

17. Viikari L, Alapuranen M, Puranen T, Vehmaanpera J, Siika-Aho M: Thermostable enzymes in lignocellulose hydrolysis. Adv Biochem Eng Biotechnol 2007, 108:121-145.

18. Contreras LM, Gómez J, Prieto J, Clemente-Jiménez JM, Las Heras-Vázquez FJ, Rodríguez-Vico F, Blanco FJ, Neira JL: The family 52 beta-xylosidase from Geobacillus stearothermophilus is a dimer: structural and biophysical characterization of a glycoside hydrolase. Biochim Biophys Acta 2008, 1784:1924-1934

19. Quintero D, Velasco Z, Hurtado-Gómez E, Neira JL, Contreras LM: Isolation and characterization of a thermostable beta-xylosidase in the thermophilic bacterium Geobacillus pallidus. Biochim Biophys Acta 2007, 1774:510-518

20. Baba T, Shinke R, Nanmori T: Identification and characterization of clustered genes for thermostable xylan-degrading enzymes, beta-xylosidase and xylanase, of Bacillus stearothermophilus 21. Appl Environ Microbiol 1994, 60:2252-2258.

21. Ratnadewi AA, Fanani M, Kurniasih SD, Sakka M, Wasito EB, Sakka K, Nurachman Z, Puspaningsih NN: $\beta$-D-xylosidase from Geobacillus thermoleovorans IT-08: biochemical characterization and bioinformatics of the enzyme. Appl Biochem Biotechnol 2013, 170:1950-1964.

22. Wagschal K, Heng C, Lee CC, Robertson GH, Orts WJ, Wong DW: Purification and characterization of a glycoside hydrolase family 43 beta-xylosidase from Geobacillus thermoleovorans IT-08. Appl Biochem Biotechnol 2009, 155:304-313.

23. Lama L, Calandrelli V, Gambacorta A, Nicolaus B: Purification and characterization of thermostable xylanase and beta-xylosidase by the thermophilic bacterium Bacillus thermantarcticus. Res Microbiol 2004, 155:283-289.

24. Eneyskaya EV, Ivanen DR, Bobrov KS, Isaeva-Ivanova LS, Shabalin KA, Savel'ev AN, Golubev AM, Kulminskaya AA: Biochemical and kinetic analysis of the GH3 family beta-xylosidase from Aspergillus awamori X-100. Arch Biochem Biophys 2007, 457:225-234.

25. Yang JK, Yoon HJ, Ahn HJ, Lee BI, Pedelacq JD, Liong EC, Berendzen J, Laivenieks M, Vieille C, Zeikus GJ, Vocadlo DJ, Withers SG, Suh SW: Crystal structure of beta-D-xylosidase from Thermoanaerobacterium saccharolyticum, a family 39 glycoside hydrolase. J Mol Biol 2004, 335:155-165.

26. Shallom D, Leon M, Bravman T, Ben-David A, Zaide G, Belakhov V, Shoham G, Schomburg D, Baasov T, Shoham Y: Biochemical characterization and identification of the catalytic residues of a family $43 \beta$-D-xylosidase from Geobacillus stearothermophilus T-6. Biochemistry 2005, 44:387-397.

27. Turner P, Mamo G, Karlsson EN: Potential and utilization of thermophiles and thermostable enzymes in biorefining. Microb Cell Fact 2007, 6:9.

28. Singh SK, Heng C, Braker JD, Chan VJ, Lee CC, Jordan DB, Yuan L, Wagschal $\mathrm{K}$ : Directed evolution of GH43 $\beta$-xylosidase XylBH43 thermal stability and L186 saturation mutagenesis. J Ind Microbiol Biotechnol 2014, 41:489-498.

29. Zhang ZG, Yi ZL, Pei XQ, Wu ZL: Improving the thermostability of Geobacillus stearothermophilus xylanase XT6 by directed evolution and site-directed mutagenesis. Bioresour Technol 2010, 101:9272-9278.

30. Klein-Marcuschamer D, Oleskowicz-Popiel P, Simmons BA, Blanch HW: The challenge of enzyme cost in the production of lignocellulosic biofuels. Biotechnol Bioeng 2012, 109:1083-1087.

31. Tu M, Zhang X, Paice M, MacFarlane P, Saddler JN: The potential of enzyme recycling during the hydrolysis of a mixed softwood feedstock. Bioresour Technol 2009, 100:6407-6415.

32. Weiss N, Börjesson J, Pedersen LS, Meyer AS: Enzymatic lignocellulose hydrolysis: improved cellulase productivity by insoluble solids recycling. Biotechnol Biofuels 2013, 6:5.

33. Kristensen JB, Felby $C$, Jørgensen $H$ : Yield-determining factors in high-solids enzymatic hydrolysis of lignocellulose. Biotechnol Biofuels 2009, 2:11.

34. Zanoelo FF, PolizeliMdMde L, Terenzi HF, Jorge JA: Purification and biochemical properties of a thermostable xylose-tolerant beta- D-xylosidase from Scytalidium thermophilum. J Ind Microbiol Biotechno/ 2004, 31:170-176.

35. Fujii T, Yu G, Matsushika A, Kurita A, Yano S, Murakami K, Sawayama S: Ethanol production from xylo-oligosaccharides by xylose-fermenting Saccharomyces cerevisiae expressing $\beta$-xylosidase. Biosci Biotechnol Biochem 2011, 75:1140-1146.
36. Kont R, Kurašin M, Teugjas $H$, Väljamäe P: Strong cellulase inhibitors from the hydrothermal pretreatment of wheat straw. Biotechnol Biofuels 2013, 6:135.

37. Zhang J, Viikari L: Xylo-oligosaccharides are competitive inhibitors of cellobiohydrolase I from Thermoascus aurantiacus. Bioresour Technol 2012, 117:286-291.

38. Qing Q, Yang B, Wyman CE: Xylooligomers are strong inhibitors of cellulose hydrolysis by enzymes. Bioresour Technol 2010, 101:9624-9630.

39. Herrmann MC, Vrsanska M, Jurickova M, Hirsch J, Biely P, Kubicek CP: The $\beta$-D-xylosidase of Trichoderma reesei is a multifunctional b-D-xylan xylohydrolase. Biochem J 1997, 321:375-381.

40. Laemmli UK: Cleavage of structural proteins during the assembly of the head of bacteriophage T4. Nature 1970, 227:680-685.

\section{Submit your next manuscript to BioMed Central and take full advantage of:}

- Convenient online submission

- Thorough peer review

- No space constraints or color figure charges

- Immediate publication on acceptance

- Inclusion in PubMed, CAS, Scopus and Google Scholar

- Research which is freely available for redistribution

Submit your manuscript at www.biomedcentral.com/submit
C BioMed Central 